\title{
Effects of Hydrolysable Tannin with or without Condensed Tannin on Alfalfa Silage Fermentation Characteristics and In Vitro Ruminal Methane Production, Fermentation Patterns, and Microbiota
}

\author{
Lei Chen ${ }^{1}$, Xueyan Bao ${ }^{1}$, Gang Guo ${ }^{1}$, Wenjie Huo ${ }^{1}$, Qingfang $\mathrm{Xu}^{2}$, Cong Wang ${ }^{1}$, Qinghong Li ${ }^{1}$ and Qiang Liu ${ }^{1, *}$ \\ 1 College of Animal Science, Shanxi Agricultural University, Taigu 030801, China; CL1016ZJ@126.com (L.C.); \\ 18235417674@163.com (X.B.); guosteel1984@163.com (G.G.); huohuo-1982@163.com (W.H.); \\ wangdx0321@163.com (C.W.); sxaulqh88@126.com (Q.L.) \\ 2 College of Grassland Science, Shanxi Agricultural University, Taigu 030801, China; xuqfsxau@126.com \\ * Correspondence: liuqiangabc@163.com; Tel.: +86-0354-628-9115; Fax: +86-0354-628-8052
}

\section{check for}

updates

Citation: Chen, L.; Bao, X.; Guo, G.; Huo, W.; Xu, Q.; Wang, C.; Li, Q.; Liu, Q. Effects of Hydrolysable Tannin with or without Condensed Tannin on Alfalfa Silage Fermentation Characteristics and In Vitro Ruminal Methane Production, Fermentation Patterns, and Microbiota. Animals 2021, 11, 1967. https://doi.org/ 10.3390/ani11071967

Academic Editor: Nassim Moula

Received: 27 April 2021

Accepted: 27 June 2021

Published: 30 June 2021

Publisher's Note: MDPI stays neutral with regard to jurisdictional claims in published maps and institutional affiliations.

Copyright: (c) 2021 by the authors. Licensee MDPI, Basel, Switzerland. This article is an open access article distributed under the terms and conditions of the Creative Commons Attribution (CC BY) license (https:/ / creativecommons.org/licenses/by/ $4.0 /)$.
Simple Summary: The sustainability of livestock husbandry requires efficient nitrogen and energy utilization by ruminants fed high-forage diets. The objective of this study was to evaluate the effect of hydrolysable tannin (HT) without or with condensed tannin (CT) on modulating the ensiling characteristics, methane production, ruminal fermentation profile, and microbiota of alfalfa silage. The results showed that adding HT, alone or in combination with CT, to alfalfa at ensiling improves fermentation quality and reduces ruminal methane production of alfalfa silage. Moreover, HT and $\mathrm{CT}$ in combination are more potent in modulating fermentation quality and methanogenesis than HT only; however, the high level of inclusion will impair silage degradation and microbiota in the rumen. Importantly, the results from this study revealed that a combination of HT and CT with complementary mechanisms at low doses can improve $\mathrm{N}$ utilization efficiency and methane mitigation of silage feed without adverse effects on ruminal fermentation patterns and microbiota. The findings in this study are of practical importance for the effective use of tannins as an additive for improving silage quality and utilization by ruminants.

Abstract: This study was conducted to evaluate the potential of hydrolysable tannin (chestnut tannin, CHT) without or with condensed tannin (quebracho tannin, QT) for modulating alfalfa silage fermentation characteristics and in vitro ruminal methane $\left(\mathrm{CH}_{4}\right)$ production, fermentation profile, and microbiota. Alfalfa (235 g/ kg fresh weight) was ensiled with no tannins (control), $2 \%$ CHT (CHT2), 5\% CHT (CHT5), the combination of CHT and QT at 1\% each (CHQ2), and CHT and QT at 2.5\% each (CHQ5) of forage dry matter (DM). The CHQ2 treatment was more effective in reducing $\mathrm{DM}$ losses, $\mathrm{pH}$, and ammonia-nitrogen to total nitrogen ratios of alfalfa silage than CHT2 and CHT5 treatments. All tannin treatments decreased ruminal $\mathrm{CH}_{4}$ production, and the magnitude of the decrease was greater for the combinations than the individual ones. Total volatile fatty acid (VFA) concentrations and DM degradation decreased by tannin treatments, but microbial protein (MCP) synthesis increased. The total VFA concentrations and DM degradation were lower with $\mathrm{CHQ} 2$ treatment than with $\mathrm{CHT} 5$ and $\mathrm{CHQ} 5$ treatments, but the MCP concentrations were comparable among these treatments. Tannin inclusion decreased the abundance of the anaerobic fungi Ruminococcus albus and Ruminococcus flavefaciens, but enhanced Fibrobacter succinogenes. The combination of CHT and QT alleviated the inhibition of CHT supply alone in Butyrivibrio fibrisolvens, Ruminobacer amylophilus, and Prevotella ruminicola as well as protease. The results revealed that a combination of HT from CHT and CT from QT at a low level can reduce proteolysis and $\mathrm{CH}_{4}$ production of alfalfa silage without impairing ruminal fermentation and microbiota.

Keywords: methane mitigation; proteolysis; ruminal fermentation; ruminal microbiota; silage; tannins 


\section{Introduction}

The livestock husbandry has long been the pillar industry of agriculture and rural economy in most developing and developed countries. Ruminants, as an important subsector of the livestock production system, have great significance to humans since they can utilize fibrous plants and by-products that are indigestible for humans to produce highprotein foods such as milk and meat [1]. However, ruminant production is accompanied by enteric methane $\left(\mathrm{CH}_{4}\right)$ emission in large quantities, leading to environmental impact. Methane production from ruminants accounts for $16-25 \%$ of the global greenhouse gas emission and about $33 \%$ of global anthropogenic $\mathrm{CH}_{4}$ emission. The $\mathrm{CH}_{4}$ emission also represents a loss of $2 \%$ to $15 \%$ of the ingested energy [2]. Besides contributing to $\mathrm{CH}_{4}$ emission, ruminants have low dietary nitrogen utilization efficiency and excrete $75 \%$ to $95 \%$ of the nitrogen intake, particularly for forage diets high in soluble protein $[3,4]$. Ultimately the excreted nitrogen exists in the form of ammonia-nitrogen $\left(\mathrm{NH}_{3}-\mathrm{N}\right)$ and nitrous oxide that can cause air and groundwater pollution. In upcoming decades, the global consumption level of beef and milk will continue to rise with increasing human population; meanwhile, these ensuing environmental problems would be increasingly prominent. Therefore, sustainable mitigation approaches for $\mathrm{CH}_{4}$ emission and nitrogen excretion are needed to be developed to improve forage conversion efficiency and alleviate the environmental impact of ruminant production.

One such promising mitigation approach is the incorporation of tannins in forage. Tannins are the second-most widespread phenolic compounds in the plant kingdom and are traditionally classified into hydrolysable tannins (HT) and condensed tannins (CT) [5]. Tannins are regarded as natural ruminant feed additives that can modulate protein metabolism [6], enteric $\mathrm{CH}_{4}$ emission, and animal performance [7]. To date, $\mathrm{HT}$ and CT have been repeatedly evaluated, mostly individually, for their efficiency to prevent proteolysis during ensiling and rumen fermentation or to reduce enteric methane production from ruminants [8-10]. However, HT and CT often exhibit negative effects on feed digestion and rumen fermentation when applied at levels high enough to obtain a desirable reduction in proteolysis and $\mathrm{CH}_{4}$ production, while they lead to little inhibition to proteolysis and methane production when applied at low levels that hardly affect feed digestion or rumen fermentation. It has been reported that HT appears to reduce proteolysis and methane production more by inhibiting functional rumen microbes, while $\mathrm{CT}$ acts more by reducing protein and carbohydrate degradation with its molecules binding capacity $[4,11]$. Thus, we hypothesized that a combination of HT and CT may be more effective in modulating proteolysis and methane mitigation with complementary mechanisms, achieving the desirable reduction of proteolysis and $\mathrm{CH}_{4}$ production at low levels without adverse effects on forage digestion or fermentation.

Alfalfa is a principal source of home-grown protein on farms and is widely used as forage for grazing cattle and dairy cows [12]. However, the protein utilization efficiency in ruminants fed alfalfa silage was normally low due to extensive proteolysis of alfalfa silage, especially natural alfalfa silage, resulting in an increase in ruminal $\mathrm{NH}_{3}-\mathrm{N}$ concentration (an indicator for $\mathrm{N}$ excretion). Therefore, the objectives of this study were to evaluate the effects of HT alone and in combination with CT at low and high levels on fermentation characteristics of high-moisture alfalfa silage and their effects on ruminal $\mathrm{CH}_{4}$ production, nutrient degradation, fermentation, enzyme activity, and microbiota.

\section{Materials and Methods}

\subsection{Forage, Treatments, and Ensiling}

The first-cut of alfalfa was harvested at the $10 \%$ bloom stage from 3 random locations in the experimental field of Shanxi Agricultural University, Taigu, China $\left(37^{\circ} 43^{\prime} \mathrm{N}\right.$, $112^{\circ} 55^{\prime} \mathrm{E}$ ). Alfalfa was chopped with a paper cutter to about $20 \mathrm{~mm}$ lengths and placed on a polyethylene sheet. Five replicated piles of forage ( $1.5 \mathrm{~kg}$ per pile) were prepared from each of the 3 locations to produce 15 total piles. The 5 piles in each location for experimental treatments were reserved in a cool sunshade area for a short time before ensiling. 
During this time, one sample from each location was obtained for chemical composition and microbial analysis of fresh forage. The chemical composition and microbial counts of fresh alfalfa are detailed in Table 1.

Table 1. Chemical composition and microbial counts of fresh alfalfa.

\begin{tabular}{lc}
\hline Item $^{\text {a }}$ & Alfalfa \\
\hline $\mathrm{DM}\left(\mathrm{g} \mathrm{kg}^{-1}\right)$ & 235 \\
$\mathrm{pH}$ & 6.31 \\
$\mathrm{Buffer} \mathrm{capacity}\left(\mathrm{mEq} \mathrm{kg}{ }^{-1} \mathrm{DM}\right)$ & 426 \\
$\mathrm{CP}\left(\mathrm{g} \mathrm{kg}^{-1} \mathrm{DM}\right)$ & 233 \\
$\mathrm{PA}\left(\mathrm{g} \mathrm{kg}^{-1} \mathrm{CP}\right)$ & 275 \\
PB $\left(\mathrm{g} \mathrm{kg}^{-1} \mathrm{CP}\right)$ & 680 \\
PC $\left(\mathrm{g} \mathrm{kg}^{-1} \mathrm{CP}\right)$ & 45 \\
$\mathrm{NDF}\left(\mathrm{g} \mathrm{kg}^{-1} \mathrm{DM}\right)$ & 306 \\
$\mathrm{ADF}\left(\mathrm{g} \mathrm{kg}^{-1} \mathrm{DM}\right)$ & 259 \\
WSC $\left(\mathrm{g} \mathrm{kg}^{-1} \mathrm{DM}\right)$ & 46.5 \\
$\mathrm{LAB}\left(\log _{10} \mathrm{cfu} \mathrm{g}{ }^{-1} \mathrm{FM}\right)$ & 4.86 \\
Yeasts $\left(\log _{10} \mathrm{cfu} \mathrm{g}^{-1} \mathrm{FM}\right)$ & 4.85 \\
\hline
\end{tabular}

${ }^{\mathrm{a}} \mathrm{DM}=$ dry matter; $\mathrm{CP}$ = crude protein; $\mathrm{PA}$ = non-protein nitrogen; $\mathrm{PB}=$ true protein; $\mathrm{PC}$ = undegradable protein $\mathrm{NDF}=$ natural detergent fiber; $\mathrm{ADF}=$ acid detergent fiber; $\mathrm{WSC}=$ water-soluble carbohydrates; $\mathrm{LAB}=$ lactic acid bacteria; $F M=$ fresh matter.

The HT extract (chestnut tannin, CHT; 92\% tannin; GEEKEE Biotech Co., Ltd., Xi'an, China) and CT extract (quebracho tannin, QT; 99\% tannin; GEEKEE Biotech Co., Ltd., $\mathrm{Xi}^{\prime}$ an, China) were kept in fine dry powder. One replicated pile from the 5 piles in each location was separately assigned to one of the following experimental treatments: no tannins (control), CHT at $20 \mathrm{~g} \mathrm{~kg}^{-1} \mathrm{DM}$ (low level; CHT2), CHT at $50 \mathrm{~g} \mathrm{~kg}^{-1} \mathrm{DM}$ (high level; CHT5), the combination of CHT and QT at $10 \mathrm{~g} \mathrm{~kg}^{-1}$ DM each (low level; CHQ2), and the combination of CHT and QT at $25 \mathrm{~g} \mathrm{~kg}^{-1} \mathrm{DM}$ each (high level; CHQ5). All tannin treatments were dissolved in distilled water and sprayed uniformly onto the chopped alfalfa (10 mL kg ${ }^{-1}$ fresh weight), and an equal dose of distilled water was applied to the control. About $1 \mathrm{~kg}$ of treated forages was packed manually into a pre-weighed polyethylene plastic bag $(26 \times 36 \mathrm{~cm})$ equipped with a one-way valve to allow gas escape. The filled bags were vacuum-sealed using a vacuum machine (YMX-958-6L, Yiminxin Co., Ltd., Quanzhou, China), weighed, and stored for $60 \mathrm{~d}$ at room temperature $\left(25-28^{\circ} \mathrm{C}\right)$. After $60 \mathrm{~d}$ of ensiling, these bags were weighed before opening to estimate DM loss (DML), and then silages were sampled for chemical and microbial analyses, as well as in vitro incubation.

\subsection{Chemical and Microbial Analyses}

Water extract was obtained from fresh and ensiled alfalfa by macerating samples $(20 \mathrm{~g})$ with deionized water $(60 \mathrm{~mL})$ for $24 \mathrm{~h}$ at $4{ }^{\circ} \mathrm{C}$, and then filtered to measure $\mathrm{pH}$, buffer capacity (BC), water-soluble carbohydrates (WSC), $\mathrm{NH}_{3}-\mathrm{N}$, and organic acids (lactic, acetic, and butyric acids). The $\mathrm{pH}$ was measured using an electrode $\mathrm{pH}$ meter (FE28, Mettler-Toledo Instruments Co., Ltd., Shanghai, China). The BC and WSC were determined with the method of Cavallarin et al. [13]. The $\mathrm{NH}_{3}-\mathrm{N}$ was measured by the method of phenolhypochlorite colorimetry, and organic acids were determined with high-performance liquid chromatography (HPLC) according to Chen et al. [14]. Fresh or ensiled alfalfa samples $(10 \mathrm{~g})$ were blended with $90 \mathrm{~mL}$ of sterilized saline solution $(\mathrm{NaCl}, 8.5 \mathrm{~g} / \mathrm{L})$ for $10 \mathrm{~min}$, and the liquid was serially diluted 10 -fold. The diluted samples were used to measure microbial counts by the plate count method. Lactic acid bacteria (LAB) and yeasts were incubated and enumerated using de Man, Rogosa, Sharpe (MRS) agar at $30{ }^{\circ} \mathrm{C}$ for $48 \mathrm{~h}$ and malt extract agar at $32{ }^{\circ} \mathrm{C}$ for $72 \mathrm{~h}$, respectively. The microbial data were presented in the form of $\log 10$ on a fresh matter basis.

Fresh or ensiled alfalfa samples (500 g) were freeze-dried and ground to pass a $1 \mathrm{~mm}$ screen with a laboratory knife mill (FW100, Taisite instrument Co., Ltd., Tianjin, China) 
for nutrients analysis. Ground samples were analyzed for DM (934.01) and total nitrogen (TN; 984.13) based on the methods of AOAC [15]. Crude protein (CP) was calculated by multiplying TN by 6.25. Neutral detergent fiber (NDF; with heat stable $\alpha$-amylase and sodium sulfite) and acid detergent fiber (ADF) were sequentially measured according to Van Soest et al. [16]. For determining proteolysis during ensiling, $\mathrm{CP}$ was divided into five fractions ( $\mathrm{PA}, \mathrm{PB}_{1}, \mathrm{~PB}_{2}, \mathrm{~PB}_{3}$, and $\mathrm{PC}$ ) through degradable characteristics according to Cornell Net Carbohydrate and Protein System (CNCPS) [17]. Briefly, PA represents nonprotein nitrogen $(\mathrm{NPN}), \mathrm{PB}_{1}$ represents rapid degradation of true protein, $\mathrm{PB}_{2}$ represents intermediate degradation of true protein, $\mathrm{PB}_{3}$ represents slow degradation of true protein, and $\mathrm{PC}$ represents undegradable protein. The five protein fractions were analyzed with standardization procedures as described by Licitra et al. [18].

\subsection{In Vitro Incubation}

Rumen fluid was collected immediately before the morning feeding from three rumen fistulated cattle fed $60 \%$ corn silage and $40 \%$ concentrate at 0700 and $1800 \mathrm{~h}$. The rumen fluid collected was homogenously mixed and strained through a sterilized muslin cloth (pore size $250 \mu \mathrm{m}$ ) into an $\mathrm{O}_{2}$-free thermos flask for use as inoculum. The substrate $(0.5 \mathrm{~g}$ of freeze-dried silage) was weighed into a pre-weighed nylon bag (pore size $38-40 \mu \mathrm{m}$; Beijing First Beef Cattle Infor \& Tech Research Center, Beijing, China), heat sealed and placed into a $100 \mathrm{~mL}$ serum bottle. Subsequently, the inoculation medium $(60 \mathrm{~mL})$, prepared aerobically with rumen inoculum $(20 \mathrm{~mL})$ and mineral buffer $(40 \mathrm{~mL})$ of Menke et al. [19], was dispensed into the serum bottles flushed with $\mathrm{CO}_{2}$. These bottles were closed with rubber stoppers and incubated in a water bath shaker at $39^{\circ} \mathrm{C}$ for $48 \mathrm{~h}$. Three independent incubation runs were conducted in three weeks. In each run, 15 sample bottles ( 5 treatments $\times 3$ replicates) and 3 bottles as blanks (inoculation medium + empty nylon bags) were prepared.

The total gas volume was recorded every $6 \mathrm{~h}$ of incubation with the pressure transducer technique and corrected with blank bottles. After measuring gas volume, the gas produced of each bottle was collected with a gas-sampling bag (Hede Technologies Co., Ltd., Dalian, China) for later $\mathrm{CH}_{4}$ analysis. After $48 \mathrm{~h}$ of incubation, the $\mathrm{pH}$ of the incubation liquid was immediately measured with the electrode $\mathrm{pH}$ meter. Thereafter, all nylon bags were retrieved from the bottles, gently squeezed by hand, and the squeezed liquid from each bag was transferred to the corresponding incubation liquid. The nylon bags were washed with running water until the water became clear and were dried at $55^{\circ} \mathrm{C}$ for $60 \mathrm{~h}$. Differences in the amounts of DM, CP, and NDF between the substrates and the undegraded residues in the nylon bags were regarded as nutrient degradation. The bottles with the incubation liquid were fully stirred, and the incubation liquid was sampled. The incubation liquid sample $(2 \mathrm{~mL})$ was kept in a centrifuge tube at $-80{ }^{\circ} \mathrm{C}$ for DNA extraction. The incubation liquid sample $(10 \mathrm{~mL})$ was centrifuged $(12,000 \times g$, $10 \mathrm{~min}, 4^{\circ} \mathrm{C}$ ), and the supernatant was kept at $-20^{\circ} \mathrm{C}$ for ruminal $\mathrm{NH}_{3}-\mathrm{N}$ and volatile fatty acid (VFA) analyses. The incubation liquid $(5 \mathrm{~mL})$ was used to determine microbial protein (MCP) using the Coomassie brilliant blue method as described by Pang et al. [20]. The $\mathrm{CH}_{4}$ concentrations of gas samples were measured with the method of carbon dioxide absorption as described by Fievez et al. [21].

\subsection{Total DNA Extraction and Real-Time PCR}

The incubation fluid samples $(2 \mathrm{~mL})$ from each bottle in each run were thawed at $4{ }^{\circ} \mathrm{C}$, pooled, and blended well before DNA extraction. Then DNA was extracted using the TIANamp stool DNA isolation kit (Tiangen Biotech Co., Ltd., Beijing, China) with the repeated bead-beating method. The quantity and quality of extracted DNA were determined with a NanoDrop 2000 spectrophotometer (Thermo Scientific, Wilmington, DE, USA), and similar DNA concentrations across samples were obtained by adjusting the volume of samples [22]. 
Primer sets used for amplifying 16S rRNA genes of eubacteria and archaea, and the $18 S$ rRNA gene of protozoa was commercially synthesized (BGI Life Tech Co., Ltd., Beijing, China; Supplementary Table S1). Primer-BLAST search of GenBank sequences was used to check the specificities of these primers. Regular PCR was used to generate sample-derived DNA standards for each qPCR assay. The procedure of amplification and specificity detection of PCR products was performed according to Du et al. [23]. The amplicons were purified using the MiniBest DNA Fragment Purification kit (Takara Biotechnology Co., Ltd., Dalian, China) and quantified using a spectrophotometer. The purified and quantified PCR products were serially diluted 10-fold with nuclease-free water to establish standard curves for targeted microbes.

The qPCR assay was performed using a StepOne Plus ${ }^{\mathrm{TM}}$ real-time PCR system (Applied Biosystems, Foster City, CA, USA). Each amplification reaction was done in duplicate with a $20 \mu \mathrm{L}$ reaction mixture that contained $10 \mu \mathrm{L}$ of Fast SYBR Green Mastermix, $0.4 \mu \mathrm{L}$ ROX Reference Dye $(50 \times), 2 \mu \mathrm{L}$ of DNA template, $6.0 \mu \mathrm{L}$ nuclease-free $\mathrm{H}_{2} \mathrm{O}$, and $0.8 \mu \mathrm{L}$ of each primer $\left(10 \mu \mathrm{mol} \mu \mathrm{L}^{-1}\right)$. The amplification condition included an initial denaturation step at $95^{\circ} \mathrm{C}$ for $10 \mathrm{~min}$, followed by 40 cycles of $95^{\circ} \mathrm{C}$ for $15 \mathrm{~s}$, optimal annealing temperature (Supplementary Table S1) for $1 \mathrm{~min}$, and an elongation at $72{ }^{\circ} \mathrm{C}$ for $30 \mathrm{~s}$.

\subsection{Statistical Analyses}

All statistical analyses were performed using SAS 9.2 (SAS Institute Inc., Cary, NC, USA) in a completely randomized design. The analysis of variance (ANOVA) was conducted using the GLM procedure of SAS 9.2. In the in vitro fermentation experiment, each incubation run represented the experimental unit. Data of the replicates of the three runs within the same sample of the substrate were averaged before statistical analysis. The model of ANOVA was as follows:

$$
\mathrm{Y}_{i}=\mu+\alpha_{i}+\varepsilon_{i}
$$

where $Y_{i}$ is the dependent variable, $\mu$ is the least-square mean, $\alpha_{i}$ is the tannin treatment effect, and $\varepsilon_{i}$ is the experimental error. Multiple comparisons between least-square means were conducted with Tukey's test, and statistical significance was declared at $p<0.05$.

\section{Results}

\subsection{Ensiling Characteristics}

Compared with the control, all tannin treatments decreased $(p<0.001)$ DML, $\mathrm{pH}$, acetic acid and butyric acid concentrations, $\mathrm{NH}_{3}-\mathrm{N}$ to $\mathrm{TN}$ ratios, and $\mathrm{LAB}$ counts, while increased DM $(p<0.001)$ and NDF $(p=0.004)$ concentrations (Table 2$)$. The decreased and increased magnitudes of these detected variables were greater for combinations of CHT and QT than CHT alone except DM and NDF. Moreover, all tannin treatments decreased $(p<0.001)$ lactic acid concentrations except CHQ2. All tannin treatments affected $(p<0.001)$ $\mathrm{PA}, \mathrm{PB}$, and $\mathrm{PB}_{2}$ proportions but had no effects on $\mathrm{PC}, \mathrm{PB}_{1}$, and $\mathrm{PB}_{3}$ proportions (Figure 1). Compared with the control, addition of tannins decreased $(p<0.001)$ the PA proportions, while increased $(p<0.001)$ the $\mathrm{PB}$ and $\mathrm{PB}_{2}$ proportions. The proportion of $\mathrm{PA}$ was lower ( $p=0.002$ for CHT5, $p<0.001$ for CHQ2 and CHQ5), but the proportion of $\mathrm{PB}(p=0.002$ for CHT5, $p<0.001$ for CHQ2 and CHQ5) and $\mathrm{PB}_{2}(p<0.001$ for CHT5, CHQ2, and CHQ5) was greater in silages produced using CHT5, CHQ2, and CHQ5 than CHT2. 
Table 2. Fermentation characteristics, microbial counts, and chemical composition of alfalfa silage treated without or with tannin additives.

\begin{tabular}{|c|c|c|c|c|c|c|c|}
\hline \multirow{2}{*}{ Item $^{A}$} & \multicolumn{5}{|c|}{ Treatments ${ }^{B}$} & \multirow{2}{*}{ SEM } & \multirow{2}{*}{$p$-Value } \\
\hline & Control & CHT2 & CHT5 & CHQ2 & CHQ5 & & \\
\hline \multicolumn{8}{|c|}{ Fermentation Characteristics } \\
\hline $\operatorname{DML}\left(\mathrm{g} \mathrm{kg}^{-1}\right)$ & $96.2^{\mathrm{a}}$ & $75.9^{b}$ & $74.1^{\mathrm{bc}}$ & $63.7^{\mathrm{d}}$ & $65.6^{\mathrm{cd}}$ & 3.17 & $<0.001$ \\
\hline $\mathrm{pH}$ & $5.32^{\mathrm{a}}$ & $5.13^{b}$ & $5.03^{c}$ & $4.92^{\mathrm{d}}$ & $5.00^{\mathrm{cd}}$ & 0.04 & $<0.001$ \\
\hline Lactic acid ( $\left.\mathrm{g} \mathrm{kg}^{-1} \mathrm{DM}\right)$ & $33.3^{a}$ & $31.3^{b}$ & $25.0^{\mathrm{d}}$ & $33.6^{\mathrm{a}}$ & $27.6^{c}$ & 0.91 & $<0.001$ \\
\hline Acetic acid ( $\left.\mathrm{g} \mathrm{kg}^{-1} \mathrm{DM}\right)$ & $18.6^{\mathrm{a}}$ & $17.0^{\mathrm{b}}$ & $13.7^{\mathrm{d}}$ & $16.0^{\mathrm{c}}$ & $14.5^{\mathrm{d}}$ & 0.46 & $<0.001$ \\
\hline Butyric acid ( $\left.\mathrm{g} \mathrm{kg}^{-1} \mathrm{DM}\right)$ & $2.35^{\mathrm{a}}$ & $0.79^{b}$ & $0.07^{\mathrm{c}}$ & $0.09^{c}$ & $0.07^{\mathrm{c}}$ & 0.24 & $<0.001$ \\
\hline $\mathrm{NH}_{3}-\mathrm{N}\left(\mathrm{g} \mathrm{kg}^{-1} \mathrm{TN}\right)$ & $120^{\mathrm{a}}$ & $88.9^{b}$ & $77.8^{\mathrm{c}}$ & $69.7^{\mathrm{d}}$ & $60.1^{\mathrm{e}}$ & 5.56 & $<0.001$ \\
\hline \multicolumn{8}{|c|}{ Microbial counts } \\
\hline LAB $\left(\log _{10} \mathrm{cfu} \mathrm{g}^{-1} \mathrm{FM}\right)$ & $7.34^{\mathrm{a}}$ & $6.84^{b c}$ & $5.88^{\mathrm{d}}$ & $6.98^{b}$ & $6.70^{c}$ & 0.23 & $<0.001$ \\
\hline Yeasts $\left(\log _{10} \mathrm{cfu} \mathrm{g}^{-1} \mathrm{FM}\right)$ & 4.26 & 4.26 & 4.23 & 4.25 & 4.24 & 0.10 & 0.856 \\
\hline \multicolumn{8}{|c|}{ Chemical composition } \\
\hline $\mathrm{DM}\left(\mathrm{g} \mathrm{kg}^{-1} \mathrm{DM}\right)$ & $215^{b}$ & $226^{a}$ & $224^{a}$ & $229^{a}$ & $228^{a}$ & 1.52 & 0.004 \\
\hline $\mathrm{CP}\left(\mathrm{g} \mathrm{kg}^{-1} \mathrm{DM}\right)$ & 233 & 228 & 230 & 227 & 229 & 1.39 & 0.720 \\
\hline NDF $\left(\mathrm{g} \mathrm{kg}^{-1} \mathrm{DM}\right)$ & $316^{\mathrm{c}}$ & $325^{b}$ & $328^{a b}$ & $326^{a b}$ & $329^{a}$ & 1.23 & $<0.001$ \\
\hline $\mathrm{ADF}\left(\mathrm{g} \mathrm{kg}^{-1} \mathrm{DM}\right)$ & 260 & 258 & 259 & 251 & 258 & 1.24 & 0.233 \\
\hline
\end{tabular}

${ }^{\mathrm{A}} \mathrm{DML}=$ dry matter loss; $\mathrm{NH}_{3}-\mathrm{N}$ = ammonia-nitrogen; $\mathrm{LAB}=$ lactic acid bacteria; $\mathrm{DM}$ = dry matter; $\mathrm{CP}$ = crude protein; NDF; neutral detergent fiber; $\mathrm{ADF}=$ acid detergent fiber. ${ }^{\mathrm{B}}$ Control $=$ no tannins; $\mathrm{CHT} 2=20 \mathrm{~g} \mathrm{~kg}^{-1} \mathrm{DM}$ of chestnut tannin; $\mathrm{CHT} 5=50 \mathrm{~g} \mathrm{~kg}{ }^{-1} \mathrm{DM}$ of chestnut tannin; $\mathrm{CHQ} 2=10 \mathrm{~g} \mathrm{~kg}^{-1} \mathrm{DM}$ of chestnut tannin $+10 \mathrm{~g} \mathrm{~kg}^{-1} \mathrm{DM}$ of quebracho tannin; $\mathrm{CHQ} 5=25 \mathrm{~g} \mathrm{~kg}^{-1} \mathrm{DM}$ of chestnut tannin $+25 \mathrm{~g} \mathrm{~kg}^{-1} \mathrm{DM}$ of quebracho tannin. Within a row, means without a common superscript letter $(\mathrm{a}-\mathrm{e})$ differ $(p<0.05)$.

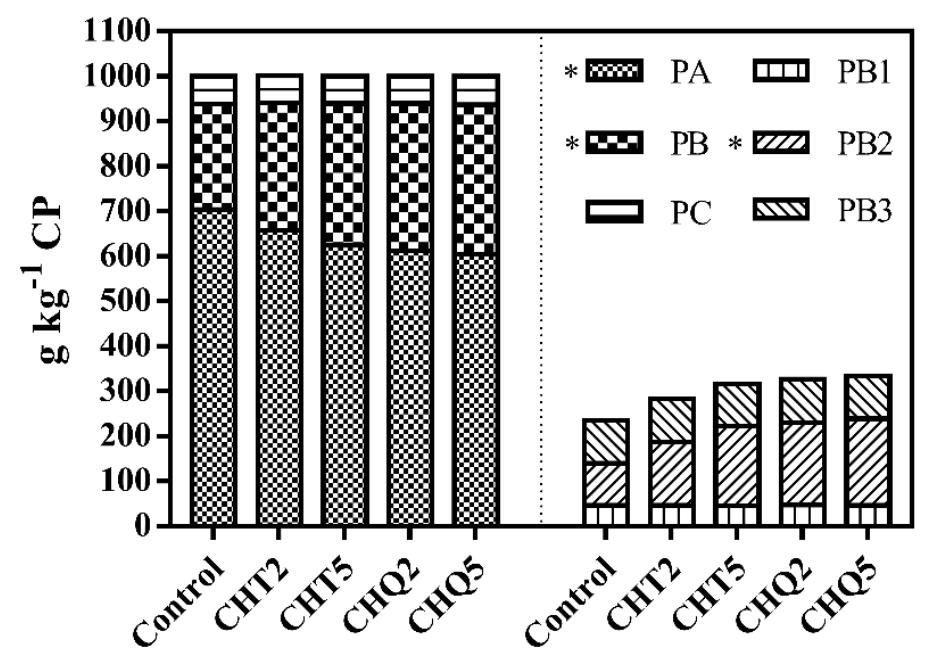

Figure 1. The effects of tannin treatments on protein fractions of alfalfa silage. Control = no additives; $\mathrm{CHT} 2=20 \mathrm{~g} \mathrm{~kg}^{-1} \mathrm{DM}$ of chestnut tannin; $\mathrm{CHT} 5=50 \mathrm{~g} \mathrm{~kg}^{-1} \mathrm{DM}$ of chestnut tannin; $\mathrm{CHQ} 2=10 \mathrm{~g} \mathrm{~kg}^{-1}$ $\mathrm{DM}$ of gallnut tannin $+10 \mathrm{~g} \mathrm{~kg}^{-1} \mathrm{DM}$ of quebracho tannin; $\mathrm{CHQ} 5=25 \mathrm{~g} \mathrm{~kg}^{-1} \mathrm{DM}$ of gallnut tannin $+25 \mathrm{~g} \mathrm{~kg}^{-1} \mathrm{DM}$ of quebracho tannin. $\mathrm{PA}=$ non-protein nitrogen; $\mathrm{PB}=$ true protein; $\mathrm{PB}_{1}=$ rapid degradation of true protein; $\mathrm{PB}_{2}=$ intermediate degradation of true protein; $\mathrm{PB}_{3}=$ slow degradation of true protein; $\mathrm{PC}=$ undegradable protein. * represents significant difference at $p<0.05$.

\subsection{Ruminal $\mathrm{Gas}$ and $\mathrm{CH}_{4}$ Production}

All gas and $\mathrm{CH}_{4}$ variables, the formation of per gram of degraded DM and NDF after $48 \mathrm{~h}$ incubation, are presented in Figure 2, respectively. Tannins, irrespective of type and level, had an inhibitory effect on gas and $\mathrm{CH}_{4}$ production, and the inhibitory effect was more evident for CHT5 and CHQ5 treatments. The combination of CHT and QT further decreased $\mathrm{CH}_{4}$ production compared with $\mathrm{CHT}$ alone, indicated by the averaged magnitude of $\mathrm{CH}_{4}$ reduction per gram of degraded DM (29.9\% vs. $\left.19.5 \%\right)$ and NDF $(28.2 \%$ vs. $18.0 \%)$ compared with the control. 
Degraded DM Degraded NDF
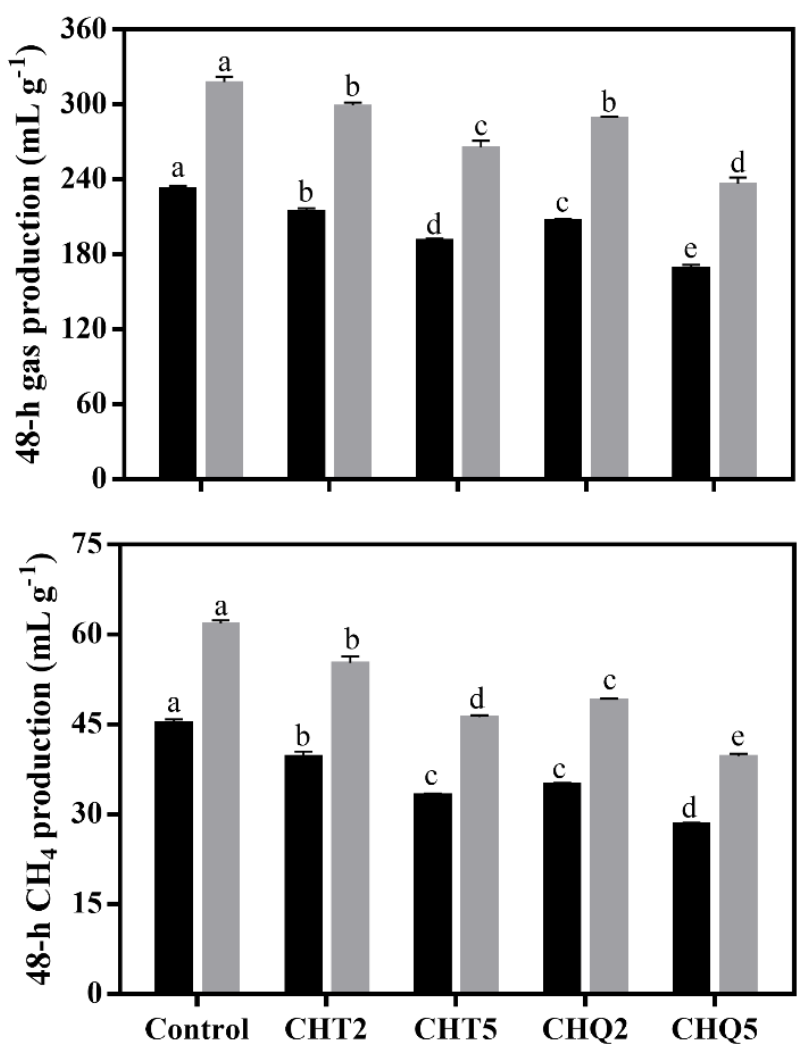

Figure 2. Gas and methane production in the in vitro fermentation cultures receiving untreated or tannin-treated alfalfa silage after $48 \mathrm{~h}$ incubation. Control = no tannins; $\mathrm{CHT} 2=20 \mathrm{~g} \mathrm{~kg}^{-1} \mathrm{DM}$ of chestnut tannin; CHT5 $=50 \mathrm{~g} \mathrm{~kg}^{-1} \mathrm{DM}$ of chestnut tannin; $\mathrm{CHQ} 2=10 \mathrm{~g} \mathrm{~kg}^{-1} \mathrm{DM}$ of chestnut tannin $+10 \mathrm{~g} \mathrm{~kg}^{-1} \mathrm{DM}$ of quebracho tannin; $\mathrm{CHQ} 5=25 \mathrm{~g} \mathrm{~kg}^{-1} \mathrm{DM}$ of chestnut tannin $+25 \mathrm{~g} \mathrm{~kg}^{-1} \mathrm{DM}$ of quebracho tannin. Error bars represent the standard error of the means $(n=3)$, and different letters (a-e) above the same color column were significant $(p<0.05)$.

\subsection{Ruminal Fermentation Patterns and Nutrient Degradation}

The CHT alone or in combinations with QT at both levels did not affect the $\mathrm{pH}$ of the incubation fluid (Table 3). Total VFA concentrations were lowered $(p<0.001)$ by all tannin treatments compared with the control. Tannin treatments affected individual VFA except acetic and butyric acids. The propionic acid molar proportions increased $(p<0.001)$ for tannin treatments, and thus, the acetic acid to propionic acid ratio decreased $(p<0.001)$. The maximum alteration occurred with CHQ5 treatment in which propionic acid proportion increased by $15.9 \%$ compared with the control. Iso-butyric, iso-valeric, and valeric acids molar proportions were lower $(p<0.001)$ for all tannin treatments. The concentration of $\mathrm{NH}_{3}-\mathrm{N}$ decreased $(p<0.001)$ with $\mathrm{CHT} 2$ and $\mathrm{CHT} 5$ treatments compared with the control, and QT inclusion at the high level further decreased this variable. The concentration of MCP was increased $(p<0.05)$ by tannin treatments, and CHT5, CHQ2, and CHQ5 treatments had greater $(p<0.001) \mathrm{MCP}$ concentrations than CHT2 treatments. The degradation of DM, CP, and NDF were lowered $(p<0.001)$ by all tannin treatments compared with the control, and CHQ5 treatment led to the lowest values. 
Table 3. Ruminal fermentation characteristics and nutrient degradation in the in vitro fermentation cultures receiving untreated and tannin-treated alfalfa silage.

\begin{tabular}{|c|c|c|c|c|c|c|c|}
\hline \multirow{2}{*}{ Item $^{A}$} & \multicolumn{5}{|c|}{ Treatments ${ }^{B}$} & \multirow{2}{*}{ SEM } & \multirow{2}{*}{$p$-Value } \\
\hline & Control & CHT2 & CHT5 & CHQ2 & CHQ5 & & \\
\hline \multicolumn{8}{|c|}{ Fermentation characteristics } \\
\hline $\mathrm{pH}$ & 6.75 & 6.79 & 6.75 & 6.79 & 6.78 & 0.01 & 0.766 \\
\hline Total VFA (mM) & $64.6^{\mathrm{a}}$ & $59.5^{b}$ & $57.8^{\mathrm{bc}}$ & $60.9^{b}$ & $55.3^{c}$ & 0.87 & $<0.001$ \\
\hline \multicolumn{8}{|c|}{ VFA, $\mathrm{mol} 100 \mathrm{~mol}^{-1}$} \\
\hline Acetic acid & 68.9 & 68.8 & 68.4 & 68.3 & 68.7 & 0.09 & 0.143 \\
\hline Propionic acid & $13.8^{\mathrm{c}}$ & $15.3^{b}$ & $15.8^{\mathrm{a}}$ & $15.9^{\mathrm{a}}$ & $16.0^{\mathrm{a}}$ & 0.22 & $<0.001$ \\
\hline Iso-butyric acid & $1.84^{\mathrm{a}}$ & $1.53^{\mathrm{b}}$ & $1.50^{b c}$ & $1.51^{\mathrm{b}}$ & $1.35^{c}$ & 0.04 & $<0.001$ \\
\hline Butyric acid & 9.29 & 9.09 & 9.06 & 9.10 & 9.03 & 0.04 & 0.346 \\
\hline Iso-valeric acid & $3.53^{\mathrm{a}}$ & $3.09^{b}$ & $3.19^{b}$ & $3.17^{b}$ & $2.85^{c}$ & 0.06 & $<0.001$ \\
\hline Valeric acid & $2.11^{\mathrm{a}}$ & $1.73^{b}$ & $1.75^{\mathrm{b}}$ & $1.76^{\mathrm{b}}$ & $1.70^{\mathrm{b}}$ & 0.04 & $<0.001$ \\
\hline Acetic acid/propionic acid & $4.98^{\mathrm{a}}$ & $4.46^{\mathrm{b}}$ & $4.30^{\mathrm{c}}$ & $4.31^{\mathrm{c}}$ & $4.28^{c}$ & 0.07 & $<0.001$ \\
\hline $\mathrm{NH}_{3}-\mathrm{N}\left(\mathrm{mg} \mathrm{dL}{ }^{-1}\right)$ & $27.0^{\mathrm{a}}$ & $23.7^{b}$ & $21.4^{\mathrm{c}}$ & $22.4^{b c}$ & $20.1^{\mathrm{d}}$ & 0.59 & $<0.001$ \\
\hline $\mathrm{MCP}\left(\mathrm{mg} \mathrm{dL}^{-1}\right)$ & $25.8^{\mathrm{c}}$ & $27.1^{b}$ & $28.5^{\mathrm{a}}$ & $28.1^{\mathrm{a}}$ & $28.2^{\mathrm{a}}$ & 0.27 & $<0.001$ \\
\hline \multicolumn{8}{|c|}{ Nutrient degradation } \\
\hline $\mathrm{DM}\left(\mathrm{g} \mathrm{kg}^{-1}\right)$ & $636^{a}$ & $617^{b}$ & $586^{c}$ & $608^{b}$ & $568^{d}$ & 6.37 & $<0.001$ \\
\hline $\mathrm{CP}\left(\mathrm{g} \mathrm{kg}^{-1}\right)$ & $861^{\mathrm{a}}$ & $840^{b}$ & $832^{\mathrm{cd}}$ & $838^{b c}$ & $829^{d}$ & 3.13 & $<0.001$ \\
\hline $\operatorname{NDF}\left(\mathrm{g} \mathrm{kg}^{-1}\right)$ & $466^{\mathrm{a}}$ & $444^{\mathrm{b}}$ & $422^{c}$ & $435^{b}$ & $406^{\mathrm{d}}$ & 5.75 & $<0.001$ \\
\hline
\end{tabular}

A VFA = volatile fatty acids; $\mathrm{NH}_{3}-\mathrm{N}=$ ammonia-nitrogen; $\mathrm{MCP}=$ microbial protein; $\mathrm{DM}=$ dry matter; $\mathrm{CP}=$ crude protein; $\mathrm{NDF}=$ neutral detergent fiber. ${ }^{\text {B }}$ Control $=$ no tannins; CHT20 $=20 \mathrm{~g} \mathrm{~kg}^{-1} \mathrm{DM}$ of chestnut tannin; CHT50 $=50 \mathrm{~g} \mathrm{~kg}^{-1}$ DM of chestnut tannin; $\mathrm{CHQ} 2=10 \mathrm{~g} \mathrm{~kg}^{-1} \mathrm{DM}$ of chestnut tannin $+10 \mathrm{~g} \mathrm{~kg}^{-1} \mathrm{DM}$ of quebracho tannin; CHQ5 $=25 \mathrm{~g} \mathrm{~kg}^{-1} \mathrm{DM}$ of chestnut tannin $+25 \mathrm{~g} \mathrm{~kg}-1$ DM of quebracho tannin. Within a row, means without a common superscript letter (a-d) differ $(p<0.05)$.

\subsection{Ruminal Enzyme Activity and Microbes}

The activity of carboxymethyl-cellulase was lower $(p=0.047, p=0.029)$ for CHT5 and CHQ5 treatments than the control (Table 4$)$. The activity of $\alpha$-amylase was lower $(p=0.008$, $p<0.001)$ for CHT2 and CHT5 treatments than the control. All tannin treatments reduced $(p<0.05)$ the activity of cellobiase, xylanase, pectinase, and protease, and CHT5 treatment resulted in the lowest values.

The abundance of total methanogens and total anaerobic fungi was lower $(p<0.001)$ for all tannin treatments than the control. Total protozoa numbers for CHT2 and CHQ2 treatments were comparable to that for the control but were lowered $(p<0.001)$ to a great extent for CHT5 and CHQ5 treatments. Tannin treatments did not affect the abundance of total bacteria; however, the bacterial groups studied differed across treatments. Compared with the control, the abundance of the cellulolytic bacteria Rumincoccus albus and Ruminococcus flavefaciens were decreased $(p<0.001)$ by tannin treatments, and the magnitude of the decrease was greater with CHT5 treatment than with other treatments, but Fibrobacter succinogenes was increased $(p<0.001)$. Abundances of the proteolytic bacteria Butyrivibrio fibrisolvens, Prevotella ruminicola, and Ruminobacer amylophilus decreased $(p<0.001)$ in response to tannin treatments. Compared with the control, the CHQ2 and CHQ5 treatments did not affect $R$. amylophilus numbers. 
Table 4. Ruminal enzyme activity and microbes in the in vitro fermentation cultures receiving untreated or tannin-treated alfalfa silage.

\begin{tabular}{|c|c|c|c|c|c|c|c|}
\hline \multirow{2}{*}{ Item } & \multicolumn{5}{|c|}{ Treatments A } & \multirow{2}{*}{ SEM } & \multirow{2}{*}{$p$-Value } \\
\hline & Control & CHT2 & CHT5 & CHQ2 & CHQ5 & & \\
\hline \multicolumn{8}{|c|}{ Enzyme activity ${ }^{\mathrm{B}}$} \\
\hline Carboxymethyl-cellulase & $0.624^{\mathrm{a}}$ & $0.604^{\mathrm{abc}}$ & $0.578^{\mathrm{bc}}$ & $0.623^{a b}$ & $0.574^{c}$ & 0.01 & 0.011 \\
\hline Cellobiase & $1.36^{\mathrm{a}}$ & $1.22^{b}$ & $1.04^{\mathrm{d}}$ & $1.17 \mathrm{bc}$ & $1.09 \mathrm{~cd}$ & 0.03 & $<0.001$ \\
\hline Xylanase & $3.35^{\mathrm{a}}$ & $2.49^{c}$ & $2.21^{\mathrm{d}}$ & $2.96^{b}$ & $2.94^{b}$ & 0.11 & $<0.001$ \\
\hline Pectinase & $3.29^{\mathrm{a}}$ & $2.55^{c}$ & $2.32^{c}$ & $2.96^{b}$ & $2.61^{\mathrm{c}}$ & 0.10 & 0.001 \\
\hline$\alpha$-amylase & $12.3^{\mathrm{a}}$ & $9.87^{b c}$ & $8.37^{\mathrm{c}}$ & $11.5^{\mathrm{ab}}$ & $11.6^{\mathrm{ab}}$ & 0.41 & $<0.001$ \\
\hline Protease & $4.93^{\mathrm{a}}$ & $4.48^{\mathrm{b}}$ & $3.66^{\mathrm{d}}$ & $4.60^{\mathrm{b}}$ & $4.65^{b}$ & 0.12 & $<0.001$ \\
\hline \multicolumn{8}{|c|}{ Microbes (copies mL ${ }^{-1}$ ) } \\
\hline Total bacteria, $\times 10^{11}$ & 1.30 & 1.37 & 1.27 & 1.35 & 1.39 & 0.04 & 0.841 \\
\hline Total anaerobic fungi, $\times 10^{7}$ & $7.74^{\mathrm{a}}$ & $5.94^{\mathrm{C}}$ & $4.41^{\mathrm{d}}$ & $6.63^{b}$ & $5.87^{\mathrm{c}}$ & 0.29 & $<0.001$ \\
\hline Total protozoa, $\times 10^{6}$ & $6.69^{\mathrm{a}}$ & $6.63^{\mathrm{a}}$ & $3.55^{b}$ & $6.68^{a}$ & $3.83^{b}$ & 0.39 & $<0.001$ \\
\hline Total methanogens, $\times 10^{8}$ & $4.08^{\mathrm{a}}$ & $3.31^{b}$ & $2.60^{\mathrm{c}}$ & $3.29^{b}$ & $2.86^{b c}$ & 0.14 & $<0.001$ \\
\hline Rumincoccus albus, $\times 10^{8}$ & $3.26^{\mathrm{a}}$ & $2.17^{\mathrm{c}}$ & $1.38^{\mathrm{d}}$ & $2.92^{b}$ & $2.21^{\mathrm{c}}$ & 0.18 & $<0.001$ \\
\hline Rumincoccus flavefaciens, $\times 10^{9}$ & $1.81^{\mathrm{a}}$ & $1.54^{\mathrm{b}}$ & $1.25^{\mathrm{d}}$ & $1.64^{b}$ & $1.41^{\mathrm{c}}$ & 0.05 & $<0.001$ \\
\hline Fibrobacter succinogenes, $\times 10^{9}$ & $3.69^{c}$ & $4.66^{\mathrm{b}}$ & $4.44^{\mathrm{b}}$ & $5.35^{\mathrm{a}}$ & $5.19^{\mathrm{a}}$ & 0.16 & $<0.001$ \\
\hline Butyrivibrio fibrisolvens, $\times 10^{7}$ & $4.12^{\mathrm{a}}$ & $2.87^{c}$ & $2.56^{c}$ & $3.68^{b}$ & $3.56^{b}$ & 0.16 & $<0.001$ \\
\hline Prevotella ruminicola, $\times 10^{10}$ & $5.63^{\mathrm{a}}$ & $3.67^{\mathrm{d}}$ & $2.91^{\mathrm{e}}$ & $4.70^{\mathrm{c}}$ & $5.16^{\mathrm{b}}$ & 0.27 & $<0.001$ \\
\hline Ruminobacer amylophilus, $\times 10^{7}$ & $2.86^{\mathrm{a}}$ & $2.44^{b}$ & $2.06^{\mathrm{c}}$ & $2.86^{\mathrm{a}}$ & $2.98^{\mathrm{a}}$ & 0.10 & $<0.001$ \\
\hline
\end{tabular}

\section{Discussion}

\subsection{Fermentation Characteristics of Alfalfa Silage}

In the present study, the addition of tannins, irrespective of type and level, improved the ensiling characteristics of alfalfa silage, as evidenced by reductions in $\mathrm{DML}, \mathrm{pH}$, acetic, and butyric acid concentrations, and $\mathrm{NH}_{3}-\mathrm{N}$ to $\mathrm{TN}$ ratios. Previous studies conducted by Li et al. [6] and Peng et al. [24] have shown similar results after tannin treatment on legume forages at ensiling. They attributed the improved fermentation efficiency to the antimicrobial properties of tannins that inhibited the undesirable microorganisms from breaking down fermentation substrates, such as proteins and carbohydrates, into silage acids, ethanol, and carbon dioxide. The growth of LAB was also inhibited by tannin treatments, as seen from the results of lactic acid and LAB, and the inhibitory effect was in a CHT dose-dependent manner. This finding suggested that HT has a greater ability to interfere with bacterial flora than CT during ensiling. Although the lactic acid fermentation was depressed in silages produced using tannin treatments, the $\mathrm{pH}$ for tannin treatments was lower than that for the control, and CHQ2 silage had the lowest $\mathrm{pH}$ value. In general, the extent of $\mathrm{pH}$ decline in silage is positively correlated to lactic acid yields during ensiling while negatively correlated to the concentration of proteolysis products such as $\mathrm{NH}_{3}-\mathrm{N}$ [9]. Thus, the variables in lactic acid and proteolysis product concentrations between these silages might contribute to the mixed $\mathrm{pH}$ values. Furthermore, $\mathrm{pH}$ is a simple indicator of the extent of silage fermentation, and $\mathrm{pH}$ with a range of 4.3 to 5.0 is acceptable for legume silages [9]. However, only the $\mathrm{pH}$ of $\mathrm{CHQ} 2$ and $\mathrm{CHQ} 5$ treatments was in this range. Together with lower $\mathrm{NH}_{3}-\mathrm{N}$ to TN ratios for $\mathrm{CHQ} 2$ and $\mathrm{CHQ} 5$ treatments than $\mathrm{CHT} 2$ and CHT5 treatments, this revealed that the combination of CHT and QT further improved silage fermentation quality than $\mathrm{CHT}$ alone.

The main concern for alfalfa silage quality is extensive proteolysis due to plant proteases and microbial activities during ensiling, which would produce large amounts of NPN compounds, consequently lowering nitrogen utilization and increasing nitrogen 
excretion into the environment by ruminants. The ensiling process resulted in extensive proteolysis of alfalfa, reflected by the changes in the proportion of PA and PB fractions before and after ensiling of alfalfa ( $265 \mathrm{vs} .703 \mathrm{~g} \mathrm{~kg}^{-\mathrm{x}} \mathrm{CP}, 685 \mathrm{vs} .235 \mathrm{~g} \mathrm{~kg}^{-\mathrm{C}} \mathrm{CP}$, respectively). Additionally, the PA proportion ( $\left.703 \mathrm{~g} \mathrm{~kg}^{-\mathrm{C}} \mathrm{DM}\right)$ for the control silage was greater than that reported by Contreras-Govea et al. [25]. This should be due to the lower DM concentration of alfalfa silage in the present study than that in their study because PA proportion is negatively correlated to DM concentration of silage [8]. Despite the similar $\mathrm{CP}$ concentration among all treatments, the decreased PA and increased PB proportions by tannin treatments clearly confirmed that tannin addition reduced the proteolysis of silage when compared with the control. Tannins have the ability to bind protein forming chemically stable complexes at pH 3.5 to 7 [26]; thus, protein in the complexes was kept from being degraded by plant proteases and microbial activities during ensiling. Regarding the composition of the $\mathrm{PB}$ fraction, the increase in $\mathrm{PB}_{2}$ proportions by tannin treatments was expected. The $\mathrm{PB}_{2}$ fraction generally degraded slowly in the rumen, leading to a high proportion of true protein flow to the intestine [6], which benefits protein utilization by ruminants. Importantly, we found that the average magnitudes of PA decrease and PB increase were greater in silages produced using combinations of CHT and QT than CHT alone, which indicated that combinations of $\mathrm{HT}$ and $\mathrm{CT}$ were more effective in reducing silage proteolysis than HT alone. Plant proteases are regarded as the primary actor in proteolysis during ensiling and initiate true protein degradation forming peptides and free amino acids, which are subsequently converted into $\mathrm{NH}_{3}$ by microbial activities. Therefore, it might be due to the fact that CT has a greater affinity to proteins and proteinases than HT [4], leading to a greater reduction in proteolysis by the combination of CHT and QT than CHT alone. Tannins can bind to fiber and thus increased the concentration of NDF.

\subsection{Gas and $\mathrm{CH}_{4}$ Production and Rumen Microbiota}

The decreased gas production for tannin treatments compared with the control indicated that tannin addition limited ruminal carbohydrate fermentation because rumen gases are primarily produced along with VFA formation from carbohydrate digestion. The decreased total VFA concentrations for tannin treatments partly supported this finding. Notwithstanding that ruminal $\mathrm{CH}_{4}$ is synthesized by methanogenic archaea using $\mathrm{H}_{2}$ and $\mathrm{CO}_{2}$ as substrates [27], it is accepted that tannins can reduce ruminal $\mathrm{CH}_{4}$ production in two ways: (1) inhibiting the activity of several rumen microbes associated with $\mathrm{CH}_{4}$ production; and (2) reducing carbohydrate digestion via forming stable complexes with carbohydrates [28].

Regarding the target rumen microbes, all tannin treatments directly decreased the abundance of total methanogens, which is the most closely associated with $\mathrm{CH}_{4}$ formation [29]. However, the magnitude of total methanogens population reductions in different tannin treatments did not match the reduction in $\mathrm{CH}_{4}$ production. This indicated that other microbial activities that reduce $\mathrm{H}_{2}$ production or provide an alternative pathway for $\mathrm{H}_{2}$ sink have been performed during in vitro fermentation. As important candidates for $\mathrm{CH}_{4}$ production, protozoa can be symbiotically associated with methanogens and serve abundant $\mathrm{H}_{2}$ for $\mathrm{CH}_{4}$ synthesis with their hydrogenosomes [30]. Previous studies have reported that removal of rumen protozoa leads to a 9-37\% decrease in $\mathrm{CH}_{4}$ production [31,32]. Thus, the decreased protozoa populations for tannin treatments only at the high level might partly cause the $\mathrm{CH}_{4}$ variables. Previous studies have reported that ruminal anaerobic fungi have a similar $\mathrm{H}_{2}$-producing system as protozoa and interact with methanogens through interspecies $\mathrm{H}_{2}$ transfer [33,34]. Thus, the decreased anaerobic fungi populations due to tannin treatments might have lowered the $\mathrm{H}_{2}$ available for methanogens and further inhibited ruminal methanogenesis. Similarly, Jayanegara et al. [11] and Khiaosa-ard et al. [35] found a reduction in the abundance of ruminal anaerobic fungi accompanied by $\mathrm{CH}_{4}$ mitigation in the fermenter that received tannins.

The major cellulolytic bacteria $R$. albus and $R$. flavefaciens are representative $\mathrm{H}_{2}$ producers and have been shown to produce $\mathrm{CH}_{4}$ when in co-culture with methanogens [36,37]. 
In the present study, all tannin treatments decreased the abundance of $R$. albus and $R$. flavefaciens and, thus, lowered the $\mathrm{H}_{2}$ available for methanogens. In addition, we found that $R$. albus was more sensitive to tannins than $R$. flavefaciens according to the magnitude of the reduction of these two bacteria population by tannin treatments. This finding is in agreement with Wang et al. [38], who showed that the abundance of $R$. albus decreased by phlorotannin at $24 \mathrm{~h}$ incubation compared with the control, but that of $R$. flavefaciens was not affected by phlorotannin over the $24 \mathrm{~h}$ incubation. However, in contrast, Khiaosa-ard et al. [35] reported that $R$. flavefaciens was more susceptible to grape seed tannins than $R$. albus. Interestingly, unlike $R$. albus and $R$. flavefaciens, the growth of major cellulolytic bacteria F. succinogenes was enhanced by tannin treatments. Given that the cell wall of bacteria is the primary site where tannins exert inhibitory action [39], the differences in the cell wall structure between F. succinogenes (Gram-negative bacteria) and the two cellulolytic ruminococcus (Gram-positive bacteria) may result in the variable sensitivities to tannins. Furthermore, F. succinogenes does not produce $\mathrm{H}_{2}$ and thus is less sensitive to $\mathrm{H}_{2}$ accumulation due to loss of methanogens than $R$. albus and $R$. flavefaciens [40]. Therefore, a compensatory increase in F. succinogenes populations may occur after a decrease in the two cellulolytic ruminococcus populations.

The CHT treatment alone possessed a greater inhibitory effect on the anaerobic fungi $R$. albus and $R$. flavefaciens than the combination of CHT and QT, as revealed by the average magnitude of microbial population reduction by these two types of tannin treatments. However, the average $\mathrm{CH}_{4}$ production of $\mathrm{CHQ} 2$ and $\mathrm{CHQ} 5$ treatments was lower than that of CHT2 and CHT5 treatments. This suggested that QT in the combinations plays a significant role in further reducing $\mathrm{CH}_{4}$ production. Generally, HT can be catabolized to acetic and butyric acids with 3-hydroxy-5-oxohexanoate pathways in the rumen [41]; thus, the inhibitory effect of $\mathrm{CHT}$ on $\mathrm{CH}_{4}$ formation may become weak due to its hydrolyzation as incubation time increases. On the other hand, CT is difficult to be degraded in the rumen and has a greater affinity to carbohydrates than HT [4]. Collectively, this indicated that QT may contribute more to $\mathrm{CH}_{4}$ mitigation than $\mathrm{CHT}$ in the later stages of in vitro incubation, and the combination of HT and CT is more effective on $\mathrm{CH}_{4}$ mitigation than $\mathrm{HT}$ alone.

\subsection{Rumen Fermentation and Rumen Microbes}

The in vitro ruminal $\mathrm{pH}$ of the treatments varied between 6.75 and 6.85 , which were within a normal range of ruminal $\mathrm{pH}$ from 5.5 to 7.0. Confirming the results of previous studies $[28,42]$, tannin treatments decreased total VFA concentrations compared with the control. The decreased VFA production corresponded to the decreased DM and NDF degradation in this study. A recent meta-analysis showed that inhibition of methanogenesis shifts the rumen fermentation toward propionic acid production in batch cultures, which is an alternative pathway for consuming reducing equivalents and $\mathrm{H}_{2}$ utilization in the rumen [43]. In addition, we observed that the propionic acid molar proportion increased along with the decrease in $\mathrm{CH}_{4}$ production by tannin treatments. It should be noted that the microbial species targeted herein account for a fraction of the rumen microbes; thus, it is hard to explain the VFA results with the rumen microbes quantified. Considering that propionic acid is primarily produced through a succinate-propionate pathway in the rumen [29], the increased propionic acid production by tannin treatments may result from the increased F. succinogenes population, known as ruminal succinate producer. Regarding the host animal, an increase in propionic acid formation through chemical treatments is energetically beneficial because the gluconeogenesis of ruminants mainly depends on propionic acid supplementation [44].

A decrease in the concentration of $\mathrm{NH}_{3}-\mathrm{N}$ represents not only reduced protein degradation during rumen fermentation but improved nitrogen utilization by rumen microbes for MCP formation. Both cases were found in tannin treatments in the present study. The first case was reflected in the decreased CP degradation by tannin treatments compared with the control and supported by depressed molar proportions of iso-valeric and iso-butyric acids, end products of deamination of feed amino acids; the second case was 
confirmed by greater MCP concentrations in tannin treatments than the control. The increase in MCP formation was most likely due to the action of tannins, which slowed down the degradation of proteins and carbohydrates and thus provided a better synchronization of available nutrients [45]. Although the concentration of MCP was greater in CHT5 treatment than $\mathrm{CHT} 2$ treatment, $\mathrm{CHQ} 5$ treatment did not further increase $\mathrm{MCP}$ production compared with $\mathrm{CHQ} 2$ treatment. This may be due to the lowest nutrient degradation for CHQ5 treatment that appeared to decrease nitrogen and energy availability for rumen microbes, which restricted more MCP formation. It is known that the metabolizable protein (MP) flow to the intestine typically contains ruminally undegradable feed protein and MCP. The decreased $\mathrm{CP}$ degradation together with increased $\mathrm{MCP}$ by tannin treatments would be highly favorable to supply more MP to the host animal, which is an effective way to improve nitrogen utilization efficiency [46].

All tannin treatments suppressed DM, CP, and NDF degradation in the present study, which was in agreement with other studies that reported decreased nutrient degradation when tannins were added to feed in vivo [47]. Besides the protein-binding effects of tannins, the negative response of $C P$ degradation to tannin treatments was due to the inhibition of the major proteolytic bacteria B. fibrisolvens, P. ruminicola, and R. amylophilus, which was reflected by the decreased proteinase activity in tannin treatments. Similarly, in addition to carbohydrate-binding effects, the decreased NDF degradation was related to the reduction in the abundance of the aforementioned cellulolytic microbes as well as the activity of cellobiase, xylanase, and pectinase by tannin treatments. The DM degradation was lower in CHQ2 and CHQ5 treatments than CHT2 and CHT5 treatments, although higher proteolytic and cellulolytic bacteria numbers were observed in CHQ2 and CHQ5 treatments than $\mathrm{CHT} 2$ and $\mathrm{CHT} 5$ treatments. This indicated that the further decreased DM degradation in CHQ2 and CHQ5 treatments is more likely due to the protein- and carbohydrate-binding capacity of tannins. As CP degradation was not affected and NDF degradation was decreased by the combination of CHT and QT than CHT alone (CHQ2 vs. CHT2 and CHQ5 vs. CHT5, respectively), the decreased DM degradation was most likely to be associated with carbohydrate fractions. Opposite to our expectation, the results indicated that tannins in this study had a greater affinity to carbohydrates than to protein. Furthermore, the results also confirmed that $\mathrm{CT}$ had a greater nutrient-binding capacity than HT.

\section{Conclusions}

Adding CHT to supply HT, alone or in combination with QT to supply CT, to alfalfa at ensiling at a low $(20 \mathrm{~g} / \mathrm{kg} \mathrm{DM})$ or high level $(50 \mathrm{~g} / \mathrm{kg} \mathrm{DM})$ reduced proteolysis, ruminal $\mathrm{CH}_{4}$ production, and $\mathrm{NH}_{3}-\mathrm{N}$ concentrations of alfalfa silage. Moreover, $\mathrm{HT}$ and $\mathrm{CT}$ in combination were more potent in modulating proteolysis and methanogenesis than HT only; however, the high level of inclusion will impair silage degradation and microbiota of the rumen. The results from this study revealed that a combination of HT and CT with complementary mechanisms at low levels can be a sustainable and effective strategy to improve the nitrogen utilization efficiency and $\mathrm{CH}_{4}$ mitigation of silage feed without adverse effects on ruminal fermentation patterns and microbiota. Further animal feeding studies are needed to validate our in vitro findings.

Supplementary Materials: The following are available online at https:/ / www.mdpi.com/article/10 .3390/ani11071967/s1, Table S1: Primers of microbes used for real-time PCR assay.

Author Contributions: Conceptualization, methodology, writing-original draft, L.C.; data curation, formal analysis, X.B.; resource, formal analysis, G.G.; investigation, visualization, W.H.; validation, Q.X.; writing-reviewing and editing, C.W.; visualization, funding acquisition, Q.L. (Qinghong Li); supervision, funding acquisition, Q.L. (Qiang Liu). All authors have read and agreed to the published version of the manuscript. 
Funding: This work was supported by funds from the Fundamental Research Program of Shanxi Province (201901D211370), Special Fund Project for the Central Government to Guide Local Science and Technology Development (YDZX20181400004330), Science and Technology Innovation Project of Shanxi Agricultural University (2020BQ04), and Animal Husbandry Key Discipline Construction program in "1331 project" of Shanxi Province.

Institutional Review Board Statement: All animal protocols in this study were reviewed and approved by the Ethics Committee of Shanxi Agricultural University (Taigu, China, permit No. SXAUEAW-2018R.F.C0201).

Informed Consent Statement: Not applicable.

Data Availability Statement: Data sharing not applicable.

Conflicts of Interest: The authors declare no conflict of interest.

\section{References}

1. Kamra, D.N.; Pawar, M.; Singh, B. Effect of Plant Secondary Metabolites on Rumen Methanogens and Methane Emissions by Ruminants; Springer: Dordrecht, The Netherlands, 2012; pp. 351-370.

2. Eckard, R.J.; Grainger, C.; de Klein, C.A.M. Options for the abatement of methane and nitrous oxide from ruminant production: A review. Livestock Sci. 2011, 130, 47-56. [CrossRef]

3. Cobellis, G.; Trabalzamarinucci, M.; Yu, Z. Critical evaluation of essential oils as rumen modifiers in ruminant nutrition: A review. Sci. Total Environ. 2016, 545, 556-568. [CrossRef]

4. Aboagye, I.A.; Masahito, O.; Ramon, C.A.; Koenig, K.M.; Iwaasa, A.D.; Ann, B.K. Effects of hydrolyzable tannin with or without condensed tannin on methane emissions, nitrogen use, and performance of beef cattle fed a high-forage diet. J. Anim. Sci. 2018, 96, 5276-5286. [CrossRef] [PubMed]

5. Mueller-Harvey, I. Unravelling the conundrum of tannins in animal nutrition and health. J. Sci. Food Agric. 2006, 86, 2010-2037. [CrossRef]

6. Li, X.; Tian, J.; Zhang, Q.; Jiang, Y.; Wu, Z.; Yu, Z. Effects of mixing red clover with alfalfa at different ratios on dynamics of proteolysis and protease activities during ensiling. J. Dairy Sci. 2018, 101, 8954-8964. [CrossRef]

7. Ugbogu, E.A.; Elghandour, M.M.; Ikpeazu, V.O.; Buendia, G.; Molina, O.M.; Arunsi, U.O.; Emmanuel, O.; Salem, A.Z. The potential impacts of dietary plant natural products on the sustainable mitigation of methane emission from livestock farming. J. Clean. Prod. 2019, 213, 915-925. [CrossRef]

8. Tabacco, E.; Borreani, G.; Crovetto, G.M.; Galassi, G.; Colombo, D.; Cavallarin, L. Effect of chestnut tannin on fermentation quality, proteolysis, and protein rumen degradability of alfalfa silage. J. Dairy Sci. 2006, 89, 4736-4746. [CrossRef]

9. He, L.; Lv, H.; Chen, N.; Wang, C.; Zhou, W.; Chen, X.; Zhang, Q. Improving fermentation, protein preservation and antioxidant activity of Moringa oleifera leaves silage with gallic acid and tannin acid. Bioresour. Technol. 2020, 297, 122390. [CrossRef]

10. Niderkorn, V.; Barbier, E.; Macheboeuf, D.; Torrent, A.; Mueller-Harvey, I.; Hoste, H. In vitro rumen fermentation of diets with different types of condensed tannins derived from sainfoin (Onobrychis viciifolia Scop.) pellets and hazelnut (Corylus avellana L.) pericarps. Anim. Feed Sci. Technol. 2020, 259, 114357. [CrossRef]

11. Jayanegara, A.; Goel, G.; Makkar, H.P.; Becker, K. Divergence between purified hydrolysable and condensed tannin effects on methane emission, rumen fermentation and microbial population in vitro. Anim. Feed Sci. Technol. 2015, 209, 60-68. [CrossRef]

12. Berard, N.C.; Wang, Y.; Wittenberg, K.M.; Krause, D.O.; Coulman, B.E.; McAllister, T.A.; Ominski, K.H. Condensed tannin concentrations found in vegetative and mature forage legumes grown in western Canada. Can. J. Plant Sci. 2011, 91, 669-675. [CrossRef]

13. Cavallarin, L.; Antoniazzi, S.; Borreani, G.; Tabacco, E. Effects of wilting and mechanical conditioning on proteolysis in sainfoin (Onobrychis viciifolia Scop) wilted herbage and silage. J. Sci. Food Agric. 2005, 85, 831-838. [CrossRef]

14. Chen, L.; Dong, Z.; Li, J.; Shao, T. Ensiling characteristics, in vitro rumen fermentation, microbial communities and aerobic stability of low-dry matter silages produced with sweet sorghum and alfalfa mixtures. J. Sci. Food Agric. 2019, 99, $2140-2151$. [CrossRef]

15. AOAC. Official Methods of Analysis, 18th ed.; Association of Official Analytical Chemists: Gaithersburg, MD, USA, 2007.

16. Van Soest, P.J.; Robertson, J.B.; Lewis, B.A. Methods for dietary fibre, neutral detergent fibre, and non-starch carbohydrates in relation to animal nutrition. J. Dairy Sci. 1991, 74, 3583-3597. [CrossRef]

17. Sniffen, C.J.; O'connor, J.D.; Van Soest, P.J.; Fox, D.G.; Russell, J.B. A net carbohydrate and protein system for evaluating cattle diets: II. Carbohydrate and protein availability. J. Anim. Sci. 1992, 70, 3562-3577. [CrossRef]

18. Licitra, G.; Hernandez, T.M.; Van Soest, P.J. Standardization of procedures for nitrogen fractionation of ruminant feeds. Anim. Feed Sci. Technol. 1996, 57, 347-358. [CrossRef]

19. Menke, K.H.; Raab, L.; Salewski, A.; Steingass, H.; Fritz, D.; Schneider, W. The estimation of the digestibility and metabolizable energy content of ruminant feedingstuffs from the gas production when they are incubated with rumen liquor in vitro. J. Agric. Sci. 1979, 93, 217-222. [CrossRef] 
20. Pang, D.G.; Yang, H.J.; Cao, B.B.; Wu, T.T.; Wang, J.Q. The beneficial effect of Enterococcus faecium on the in vitro ruminal fermentation rate and extent of three typical total mixed rations in northern China. Livestock Sci. 2014, 167, 154-160. [CrossRef]

21. Fievez, V.; Babayemi, O.J.; Demeyer, D. Estimation of direct and indirect gas production in syringes: A tool to estimate short chain fatty acid production requiring minimal laboratory facilities. Anim. Feed Sci. Technol. 2005, 123, 197-210. [CrossRef]

22. Mullins, C.R.; Mamedova, L.; Carpenter, A.; Ying, Y.; Allen, M.; Yoon, I.; Bradford, B. Analysis of rumen microbial populations in lactating dairy cattle fed diets varying in carbohydrate profiles and Saccharomyces cerevisiae fermentation product. J. Dairy Sci. 2013, 96, 5872-5881. [CrossRef]

23. Du, H.S.; Wang, C.; Wu, Z.Z.; Zhang, G.W.; Liu, Q.; Guo, G.; Huo, W.J.; Zhang, Y.L.; Pei, C.X.; Zhang, S.L. Effects of rumenprotected folic acid and rumen-protected sodium selenite supplementation on lactation performance, nutrient digestion, ruminal fermentation and blood metabolites in dairy cows. J. Sci. Food Agric. 2019, 99, 5826-5833. [CrossRef] [PubMed]

24. Peng, K.; Jin, L.; Niu, Y.D.; Huang, Q.; McAllister, T.A.; Yang, H.E.; Denise, H.; Xu, Z.J.; Acharya, S.; Wang, S.X.; et al. Condensed tannins affect bacterial and fungal microbiomes and mycotoxin production during ensiling and upon aerobic exposure. Appl. Environ. Microbiol. 2018, 84, e02274-17. [CrossRef] [PubMed]

25. Contreras-Govea, F.E.; Muck, R.E.; Mertens, D.R.; Weimer, P.J. Microbial inoculant effects on silage and in vitro ruminal fermentation, and microbial biomass estimation for alfalfa, bmr corn, and corn silages. Anim. Feed Sci. Technol. 2011, 163, 2-10. [CrossRef]

26. Makkar, H.P.S. Effects and fate of tannins in ruminant animals, adaptation to tannins, and strategies to overcome detrimental effects of feeding tannin-rich feeds. Small Ruminant Res. 2003, 49, 241-256. [CrossRef]

27. Kumar, S.; Choudhury, P.K.; Carro, M.D.; Griffith, G.W.; Dagar, S.S.; Puniya, M. New aspects and strategies for methane mitigation from ruminants. Appl. Microbiol. Biotechnol. 2014, 98, 31-44. [CrossRef]

28. Min, B.R.; Castleberry, L.; Allen, H.; Parker, D.; Waldrip, H.; Brauer, D.; Willis, W. Associative effects of wet distiller's grains plus solubles and tannin-rich peanut skin supplementation on in vitro rumen fermentation, greenhouse gas emissions, and microbial changes. J. Anim. Sci. 2019, 97, 4668-4681. [CrossRef]

29. Lan, W.; Yang, C. Ruminal methane production: Associated microorganisms and the potential of applying hydrogen-utilizing bacteria for mitigation. Sci. Total Environ. 2019, 654, 1270-1283. [CrossRef]

30. Belanche, A.; Fuente, G.D.L.; Newbold, C.J. Study of methanogen communities associated with different rumen protozoal populations. FEMS Microbiol. Ecol. 2014, 90, 663-667. [CrossRef]

31. Morgavi, D.P.; Forano, E.; Martin, C.; Newbold, C.J. Microbial ecosystem and methanogenesis in ruminants. Animal 2010, 4, 1024-1036. [CrossRef]

32. Newbold, C.J.; de la Fuente, G.; Belanche, A.; Ramos-Morales, E.; McEwan, N.R. The role of ciliate protozoa in the rumen. Front. Microbiol. 2015, 6, 1313. [CrossRef]

33. Mountfort, D.O.; Asher, R.A.; Bauchop, T. Fermentation of cellulose to methane and carbon dioxide by a rumen anaerobic fungus in a triculture with Methanobrevibacter sp. Strain RAl and Methanosarcina barkeri. Appl. Environ. Microbiol. 1982, 44, 128-134. [CrossRef]

34. Patra, A.K.; Park, T.; Kim, M.; Yu, Z. Rumen methanogens and mitigation of methane emission by anti-methanogenic compounds and substances. J. Anim. Sci. Biotechnol. 2017, 8, 1-18. [CrossRef]

35. Khiaosa-Ard, R.; Metzler-Zebeli, B.U.; Ahmed, S.; Muro-Reyes, A.; Deckardt, K.; Chizzola, R.; Böhm, J.; Zebeli, Q. Fortification of dried distillers grains plus solubles with grape seed meal in the diet modulates methane mitigation and rumen microbiota in Rusitec. J. Dairy Sci. 2015, 98, 2611-2626. [CrossRef]

36. Latham, M.J.; Wolin, M.J. Fermentation of cellulose by Ruminococcus flavefaciens in the presence and absence of Methanobacterium ruminantium. Appl. Environ. Microbiol. 1977, 34, 297-301. [CrossRef] [PubMed]

37. Miller, T.L.; Currenti, E.; Wolin, M.J. Anaerobic bioconversion of cellulose by Ruminococcus albus, Methanobrevibactor smithii, and Methanosarcina barkeri. Appl. Microbiol. Biotechnol. 2000, 54, 494-498. [CrossRef]

38. Wang, Y.; Alexander, T.W.; Mcallister, T.A. In vitro effects of phlorotannins from Ascophyllum nodosum (brown seaweed) on rumen bacterial populations and fermentation. J. Sci. Food Agric. 2009, 89, 2252-2260. [CrossRef]

39. Mcallister, T.A.; Martinez, T.; Bae, H.D.; Muir, A.D.; Yanke, L.J.; Jones, G.A. Characterization of condensed tannins purified from legume forages: Chromophore production, protein precipitation, and inhibitory effects on cellulose digestion. J. Chem. Ecol. 2005, 31, 2049-2068. [CrossRef]

40. Mitsumori, M.; Shinkai, T.; Takenaka, A.; Enishi, O.; Higuchi, K.; Kobayashi, Y.; Mcsweeney, C.S. Responses in digestion, rumen fermentation and microbial populations to inhibition of methane formation by a halogenated methane analogue. Br. J. Nutr. 2012, 108, 482-491. [CrossRef]

41. McSweeney, C.S.; Palmer, B.; McNeill, D.M.; Krause, D.O. Microbial interactions with tannins: Nutritional consequences for ruminants. Anim. Feed Sci. Technol. 2001, 91, 83-93. [CrossRef]

42. Dschaak, C.M.; Williams, C.M.; Holt, M.S.; Eun, J.S.; Young, A.J.; Mint, B.R. Effects of supplementing condensed tannin extract on intake, digestion, ruminal fermentation, and milk production of lactating dairy cows. J. Dairy Sci. 2011, 94, 2508-2519. [CrossRef] [PubMed]

43. Jayanegara, A.; Leiber, F.; Kreuzer, M. Meta-analysis of the relationship between dietary tannin level and methane formation in ruminants from in vivo and in vitro experiments. J. Anim. Physiol. Anim. Nutr. 2012, 96, 365-375. [CrossRef] [PubMed] 
44. Overton, T.; Waldron, M. Nutritional management of transition dairy cows: Strategies to optimize metabolic health. J. Dairy Sci. 2004, 87, E105-E119. [CrossRef]

45. Grosse Brinkhaus, A.; Bee, G.; Schwarm, A.; Kreuzer, M.; Dohme-Meier, F.; Zeitz, J.O. Rumen microbial protein synthesis and nitrogen efficiency as affected by tanniferous and non-tanniferous forage legumes incubated individually or together in rumen simulation technique. J. Sci. Food Agric. 2018, 98, 1712-1718. [CrossRef] [PubMed]

46. Tamminga, S. A review on environmental impacts of nutritional strategies in ruminants. J. Anim. Sci. 1996, 74, 3112-3124. [CrossRef] [PubMed]

47. Aguerre, M.J.; Capozzolo, M.C.; Lendoni, P.; Cabral, C.; Wattiaux, M.A. Effect of quebracho-chestnut tannin extracts at 2 dietary crude protein levels on performance, rumen fermentation, and nitrogen partitioning in dairy cows. J. Dairy Sci. 2016, 99, 4476-4486. [CrossRef] [PubMed] 